and International Conference Art, Illustration and Visual Culture in Infant and Primary Education

\title{
Érase una vez....el cuento infantil desde la perspectiva del artista
}

Rut Martín Hernández rutmartinhernandez@gmail.com Universidad Complutense de Madrid, España

\section{Reference}

Hernandéz, Rut Martín; (2012) "Érase una vez....el cuento infantil desde la perspectiva del artista", p. 168-172 . In: Barbosa Helena; Quental, Joana [Eds]. Proceedings of the 2nd International Conference of Art, Illustration and Visual Culture in Infant and Primary Education. São Paulo: Blucher, 2015.

ISSN 2318-695X, ISBN: 978-989-98185-0-7 DOI 10.5151/edupro-aivcipe-33

Esta comunicación investiga la incursión del artista Antonio Saura en la ilustración de cuentos infantiles. En su obra "El nuevo Pinocho" ilustra el texto de la escritora Christine Nöstlinger. Se plantean las aportaciones de un artista que habitualmente realiza su práctica a través de otros medios y cómo esta incursión resulta positiva para concluir que supone un vínculo enriquecedor, tanto a nivel artístico como en el ámbito de la ilustración. Se analiza en primer lugar, a modo de contextualización, la importancia de la imagen en la configuración de la realidad en el niño y su relación con las estrategias textuales en este tipo de libros. En segundo lugar, se indaga en los intereses que llevaron a Saura a realizar esta obra, para terminar estudiando los logros y las adaptaciones que tuvo que efectuar de las características propias de su obra artística para las ilustraciones realizadas en este libro.

Libro ilustrado, Antonio Saura, imagen, estrategias visuales, niño.

\section{Abstract}

This paper analyzes the work as an illustrator of children's books of the Spanish painter Antonio Saura. In his book "The New Pinocchio" illustrates the text of the writer Christine Nöstlinger. This research deals with the contributions of an artist who usually works in other disciplines and concluded that an association rewarding, both in artistic and illustration. Is analyzed first, by way of contextualization, the importance of image in the configuration of reality in the child and their relationship to the textual strategies of these books. Second, we examine the Saura interests when carrying out this work, to complete the study with the adjustments that had to do to solve the images in this book.

\section{Introducción}

En la historia de la ilustración infantil ha habido ocasiones en las que artistas plásticos provenientes de otras disciplinas han colaborado con escritores para realizar unas obras en las que la puesta en marcha de estrategias visuales y verbales están en función de un espectador con unas características muy concretas: el niño.

Se parte de una historia creativa específica que está en relación directa con la obra que dichos autores realizan, basada en unos intereses conceptuales, formales y técnicos que definen su trayectoria y que, a menudo, están compuestos de signos identificativos capaces de crear un lenguaje propio de carácter muy personal. Esto supone, a menudo, que estos libros ilustrados por artistas que han obtenido prestigio en otras disciplinas, son más libres en cuanto a los códigos que suelen identificar el género, abiertos a más interpretaciones, menos estereotipados y a una hibridación interdisciplinar que normalmente enriquece tanto la parte formal y técnica del trabajo como la conceptual. 
2nd International Conference

Art, Illustration and Visual Culture

in Infant and Primary Education $2^{\circ}$ Congreso Internacional

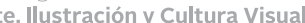
en Educación Infantil y Primaria (n)

de Arte, Ilustração e Cultura Visual

na Educação Infantil e Primária

Esta investigación ha tratado de analizar el acercamiento de Antonio Saura a la ilustración infantil, a través del estudio del libro "El nuevo Pinocho" realizado en asociación con la escritora Chistine Nöstlinger que reinterpreta el clásico de Carlo Collodi. La primera edición de este volumen data de 1994, año en el que recibió el premio al mejor libro de arte editado en España, hecho que pone de manifiesto un modo de entender el libro ilustrado, más allá de categorías impuestas, ligándolo a lo artístico. Si bien la idea del libro como obra de arte proviene de los primeros libros realizados a mano, en la actualidad el arte y el libro ilustrado convergen en un espacio abierto a la posibilidad de experimentar y aprender el mundo desde el arte a edades más tempranas. "Todos nosotros, y no sólo los niños, nos beneficiamos de la oportunidad de manipular y sentir lo que son en esencia obras de arte. Cuando una visión artística personal y única se combina con la capacidad de establecer contacto con las mentes y los corazones desde el mundo de la infancia, se despierta la magia" (Salisbury; Styles, 2012: 50).

En este sentido, este libro tiene que entenderse dentro de la obra de Antonio Saura, no como una incursión externa a un disciplina ajena, sino como parte de un discurso creativo con unas constantes comunes que se combinan con los intereses propios de la otra creadora, Chistine Nöstlinger, para llegar a una serie de acuerdos que fundamentan su coherencia e interés. Este libro fue reeditado en el año 2010 por la Fundación Archives Antonio Saura, el Museo Nacional Centro de Arte Reina Sofía y Ediciones la Central y forma parte del trabajo de conservación y difusión de la obra del difunto artista aragonés.

Dentro del proceso de investigación se han planteado unas unidades de análisis que suponen un acercamiento analítico a la obra objeto de estudio. En primer lugar, se presenta una reflexión en torno a la relación y la combinación de las estrategias verbales y visuales en el libro ilustrado, un vínculo que influencia de forma directa la comprensión y la conformación de la realidad en el niño, capaz de estructurar a partir del mismo, ciertos códigos culturales y sociales. A partir de estas cuestiones, se plantea la especificidad que tiene un libro infantil ilustrado por un artista plástico y si éste se produce desde una visión diferente capaz de evidenciar las constantes propias del artista. Por último, se aborda cómo se readaptan dichas constantes a un contexto diferente, en el que las variables del espacio de representación cambian y el espectador al que va dirigida la obra también, incidiendo en la capacidad de la obra para cuestionar los convencionalismos asociados a la infancia.

\section{Capítulo I. El maravilloso viaje desde las imágenes a las palabras. Un camino de doble sentido.}

Hay que tener en cuenta la importancia del dibujo en la configuración de la realidad en el niño. El sistema de signos, los modos de representación simbólica que se ponen en marcha cuando el niño dibuja o interpreta una historia a partir de las imágenes es fundamental y supone, como explica Luisa María Martínez García, que "el niño tiene que crear y consolidar una construcción semiótica que, como todo lenguaje, constituye una estructura con tres capas o dimensiones: la sintética, la semántica y la pragmática" (Martínez García, 2004: 26). En este sentido se entiende la importancia que adquieren de los libros ilustrados en la evolución y desarrollo del niño. Arheheim reflexionaba sobre cómo el sistema educativo sigue basándose en palabras y números, de tal forma que en las guarderías se utilizan estrategias de aprendizaje muy visuales, ejercitando la mente a través de la percepción, aspectos que se pierden cuando el niño continua la siguiente etapa educativa, en la que los sentidos empiezan a perder estatus (Arnheim, 2002).

Vivimos en un mundo cada vez más visual, rodeados de imágenes a las que no somos inmunes. Es necesario empezar a educar desde las etapas más tempranas del desarrollo a observar, valorar e interpretar el material visual. Los libros ilustrados son uno de los recursos más importantes para enseñar a mirar y a evaluar textos visuales, algo que sin duda seguiremos haciendo el resto de nuestras vidas a pesar del cambio en los soportes y en las narrativas. "Los libros ilustrados son un medio a través del cuál integramos a los niños en la cultura" (Salisbury; Styles, 2012:75). En el libro "El arte de ilustrar libros infantiles" se describe el proyecto llevado a cabo por Evelyn Arizpe y Morag Slyles, durante los años 1999 y 2001, en el que se estudiaron las reacciones de niños a distintos libros. La investigación puso de manifiesto cómo cuando los niños dibujan y hablan de libros ilustrados están revelando su conciencia cognitiva y emocional. "Los dibujos de los libros ilustrados comunican gran cantidad de cosas y son mucho más 
2nd International Conference Art, Illustration and Visual Culture in Infant and Primary Education (lional

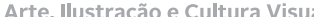

na Educação Infantil e Primária

que una pista servil, bajo las órdenes de las palabras: a menudo, las imágenes portan todo el significado" (Salisbury, 2007: 6).

Dado el potencial significativo de la imagen y la permeabilidad de los niños a estas cuestiones es fundamental plantear y analizar aquellos acercamientos al tema que sean relevantes. Según Ana García Varás, el pensamiento de Ernet Jünger describe de forma clarificadora cómo la imagen es un punto central a partir del cual se articulan conceptos y se delinean narrativas y Hans Jonas plantea cómo "es la capacidad de imaginar, es decir la imaginación (Einbildusgskraft), la condición básica y fundamental. (...) Es ese primer poder, el de imaginar, el que establece las posibilidades básicas, dado que permite el movimiento de "retirada a la conciencia", movimiento que dará paso a la abstracción" (García Varas, 2011: 35).

Por otra parte, esos primeros acercamientos al libro ilustrado suponen también la asimilación, por parte del niño, de ciertos códigos sociales y culturales y el afianzamiento de determinados roles. Por ello es interesante proponer alternativas a la creación de mundo binarios, tan propios en muchas ocasiones de las historias dirigidas a los niños, en las que se reproducen unos roles perjudiciales que después ven su continuidad en el comportamiento infantil y en su posterior etapa adulta. Son de agradecer los libros en los que, como el "Nuevo Pinocho" de Saura, tengan cabida la esperanza pero también supongan un análisis a las cualidades humanas, con sus dramas y miserias. Un acercamiento a una representación que, por otra parte, educa en cuestiones plásticas, artísticas, culturales y aporta claves de interpretación de la imagen como punto de partida para entender el mundo en el que vivimos.

2 Capítulo II. De cuando el artista plástico se sumerge en la ilustración de un libro para niños.
Es curioso reseñar cómo la mayoría de las biografías de Antonio Saura marcan como inicio de su trayectoria artística la convalecencia que lo mantuvo inmovilizado durante cinco años (cuando tenía 13 años), mientras se recuperaba de tuberculosis. A buen seguro, ese interés nació de forma paralela a su pasión por los libros que se puso de manifiesto a lo largo de su vida, en la que ilustró desde clásicos de literatura como "El Quijote" hasta libros infantiles como el que es objeto de esta investigación. Durante este tiempo creo un espacio compuesto de libros, música, imágenes y pensamientos. No en vano, su primera exposición la realizó en la librería "Libros" de Zaragoza en el año 1950 y, al año siguiente, publicó el manifiesto "Programio" de carácter poético-pictórico e inspiración surrealista. Es evidente que el vínculo entre la palabra escrita y la pintura está presente desde los inicios de la carrera del artista. "Para Saura, el acto de escribir, de dibujar, de grabar o de pintar nunca se confunden. En apariencia, cada uno se despliega en su propio espacio. En realidad, todo está en todo" (Weber-Caflisch, 2006: 12).

Parece que ese carácter vivencial con el que inició las primeras incursiones en el mundo de la pintura está también presente en la realización de este libro que realizó durante el proceso de duelo sufrido por la muerte de su hija Ana. Saura explica al respecto:

La realización de Pinocho ha constituido para mí una lúcida y gozosa tentativa de devolver al universo de lo aproximadamente inteligible una infantil y perseverante fijación. Tal evidencia, sin embargo, ha sido acompañada por la tragedia, transformándose su deseada frescura ya no en infantil nostalgia del dominio perdido, sino en el pesaroso y largo paralelismo con el dolor para transformarse al fin en esperanza y homenaje a una nueva vida" (Nöstlinger, 2010: 295).

Dentro de las razones por las cuales Antonio Saura decide realizar este libro también se encuentra un interés personal por este cuento clásico que contiene dosis de lo que él mismo denomina "crueldad y tragedia". Al artista le atrae cómo conviven en la historia estos aspectos dramáticos de la infancia y la diferencia frente al mundo adulto, tomando forma en un muñeco viviente que lucha por ser humano a pesar de la imposibilidad biológica de serlo.

Se puede observar en su faceta como ilustrador, un interés por revisar textos clásicos y dotarlos de una imaginería distinta, lograr una identificación con unos personajes que forman parte de la imaginación colectiva pero, a su vez, deconstruir el icono, contemporaneizándolo, trayéndolo hasta el presente. Es cierto que la educación visual del niño está influenciada por el contexto histórico del momento en el que vive. La mirada de los niños no es la misma en 1882 (año de 
2nd International Conference

Art, Illustration and Visual Culture

in Infant and Primary Education $2^{\circ}$ Congreso Internaciona

Arte, Ilustración y Cultura Visual en Educación Infantil y Primaria
Congresso Internacional

de Arte, llustracão e Cultura Visual

na Educação Infantil e Primária

\section{Capítulo III. La aventura de cambiar el contexto. "El nuevo Pinocho".}

la publicación del libro original escrito por Carlo Collodi) que algo más de un siglo después, cuando se edita este libro. Es por esto, por lo que las aportaciones de Saura a la representación de Pinocho resultan tan interesantes, más allá del plano formal, técnico y estético. "Los mejores ilustradores son aquellos que respetan a sus jóvenes lectores y que nunca les dan menos de lo que merecen" (Salisbury; Styles, 2012: 82).

Saura realiza las ilustraciones de "El nuevo Pinocho" pocos años antes de su muerte y vuelca en él toda la experiencia de una vida dedicada al arte y de anteriores incursiones en el mundo de la ilustración, para ofrecer un leguaje depurado, en el que su estilo personal dialoga a la perfección con las necesidades del público infantil al que va dirigido.

Las constantes de representación del artista se adaptan, en este caso, a varios condicionantes y lo hacen de forma ejemplar. Existe una adaptación de la iconografía a una narrativa específica externa a las bases conceptuales del autor. "La auténtica particularidad artística de la ilustración reside, sin duda, en una parcial independencia creadora al estar condicionada por su relación con el texto literario" (García Padrino, 2004: 19). La tarea de representar en imágenes la historia relatada por otro, en este caso la autora Chistine Nöstlinger, suponen un proceso de investigación que comienza con el conocimiento de las adaptaciones posteriores que se han realizado de este cuento infantil y, termina, con la creación de un universo compuesto de imágenes y textos que encaja y discurre al unísono. Ese vínculo es indispensable para transmitir el significado global que, además, funciona de forma dinámica. Hay que mencionar que en este libro existe una prioridad visual y se considera que esa, precisamente, es una de las especificidades de estar ilustrado por un artista que suele trabajar con otros medios y soportes.

Se trata por otra parte de establecer una relación secuencial de imágenes en base a un relato de carácter lineal. Esto no suele ocurrir en las obras artísticas que funcionan de manera independiente o seriada y que ocupan un espacio de carácter tridimensional que supone una adaptación al formato del libro ilustrado. Las imágenes creadas para otro contexto que no es el "cubo blanco", ni la mirada vertical a distancia del espectador pasivo, implica un formato constante, un tipo de soporte específico, en el que solucionar composiciones diferentes, grafismos y gamas cromáticas acordes con el sistema de impresión. Saura lo soluciona de manera muy creativa jugando los elementos propios de la plástica de tal manera que el conjunto se muestra heterogéneo pero coherente. "El dibujo supone la transposición a otro orden de los datos oportunos obtenidos de la realidad, y satisface al niño en la medida en que cumple las condiciones que exige la representación gráfica y sus propias expectativas" (Martínez García, 2004:188). No hay que olvidar que el lector, en este caso el niño, por sus características necesita sentirse empujado para continuar con el relato y Saura, a través de sus dibujos, logra mantener el interés, la curiosidad y el placer del descubrimiento página tras página.

Quizá el mayor acierto de este libro sea la adaptación de un lenguaje tan personal como el de Saura a un cambio de espectador. Estas imágenes ya no están dirigidas al espectador adulto que visita centros de arte, ni a aquel que disfruta con obras clásicas de la literatura universal, como podían ser las anteriores incursiones en el mundo de la ilustración llevadas a cabo por el artista aragonés. Esta obra está dirigida a un niño, cuyos códigos de lectura de la imagen son diferentes y están condicionados por una permeabilidad para la comprensión de signos visuales capaces de comportar y afianzar determinados comportamientos y roles sociales, con una influencia directa en su conformación de la realidad. "Muchos artistas hablan de la búsqueda del ojo inocente en su trabajo, una búsqueda que dura toda la vida. En otras palabras, expresan el deseo de desaprender, de desechar las habilidades y los manierismos y de aprender a ver el mundo a través de los ojos de un niño" (Salisbury; Styles, 2012: 57). Son todas estas cuestiones las que hay que poner en marcha en el momento de enfrentarse a la tarea de ilustrar un libro infantil y Saura, además, parte de un bagaje plástico y conceptual muy concreto, unos modos de hacer que pasan de la pincelada influenciada por el "action painting" de sus pinturas a la gráfica propia de su obra múltiple, de los grandes formatos a tamaño reducido de un libro, de la reducción de la paleta a la libertad cromática. "No le afecta, al menos a la hora de lo que él ha llamado con propiedad "la batalla del lienzo", el lugar donde está; lleva consigo a cuestas sus obsesiones, y con ellas construye una suerte de biombo, de muralla, de estudio portátil" (Bonet; 
2nd International Conference Art, Illustration and Visual Culture in Infant and Primary Education de Arte, llustração e Cultura Visual

na Educação Infantil e Primária

Maderuelo, 1997: 90). Desde el punto de vista conceptual, transforma un lenguaje que indaga en "los grandes temas" con un gran componente dramático, como la muerte, la religión, el sexo o la violencia, constantes en su trayectoria artística, a un relato que a pesar del componente dramático mencionado en la introducción está lleno de esperanza.

Es muy interesante como ese flujo de imágenes que va sucediéndose a lo largo del relato está compuesta por distintas tipologías entre las que destacan la iconografía creada para la personificación de Pinocho y el resto de los personajes del libro, las imágenes realizadas a base de grafismos de línea de carácter más abstracto y aquellas que remiten a sus series de obra múltiple, más cercanas a las soluciones adoptadas en su obra realizada en otras disciplinas, más pictóricas y que sirven de nexo de unión de ese lenguaje propio al que se hacía referencia con el específico creado para esta ocasión. "Su realización ha sido dificultosa debido esencialmente a un problema que ya había surgido cuando ilustré Don Quijote de la Mancha: la necesidad de identificación del personaje y, al mismo tiempo, la obligación de salvaguardar el personal grafismo sin realizar penosas concesiones" (Nöstlinger, 2010: 294). El reto era construir un personaje que tuviera que ver su propio lenguaje, partiendo de la idea de que el cambio de espectador impedía concurrir en excesivas libertades o deformaciones, a la vez que existía una voluntad de no caer en una estética naif, blanda y estereotipada. El artista "quería que la obra fuese comprendida y aceptada por los niños -ese era su objetivo fundamental-" (Nöstlinger, 2010: 294).

\section{Conclusión}

Del análisis del libro "El nuevo Pinocho" ilustrado por Antonio Saura se desprende el interés de la incursión dentro del mundo de la ilustración para niños de artistas que desarrollan habitualmente su labor artística a través de otros medios y disciplinas. Se considera que las aportaciones fundamentales, en este caso concreto, son: 1) una mayor reflexión de la importancia del significado de la imagen, manteniendo un discurso de igualdad con respecto al texto o, como en este caso, priorizando lo visual. 2) La configuración de una retórica visual más libre, menos condicionada por los estereotipos formales y conceptuales propios del género. 3) El establecimiento de una iconografía personal ligada a la trayectoria artística de Antonio Saura, con el interés artístico que esto supone, adaptada e interpretada para que sea comprensible para un nuevo espectador - lector, el niño. 4) La actualización y contemporaneización de clásicos de la literatura infantil, desde la perspectiva de aquel que está acostumbrado a "hablar con imágenes" que logra, así, un universo muy particular cuya representación está en consonancia con las manifestaciones artísticas de finales de siglo XX.

\section{Referencias bibliográficas}

Arnheim, R. (2002). Arte y percepción visual. Madrid: Alianza.

Salisbury, M.; Styles, M. (2012). El arte de ilustrar cuentos infantiles. Concepción y práctica de la narración visual. Barcelona: Art Blume.

Salisbury, M. (2007). Imágenes que cuentan. Nueva ilustración de libros infantiles. Barcelona: Gustavo Gili Martínez García, L.Mả. (2004). Arte y símbolo en la infancia. Un cambio de mirada. Barcelona: Octaedro. García Varas, A. (2011). Filosofía de la imagen. Salamanca: Ediciones Universidad de Salamanca

Weber- Caflisch, O. (2006). Antonio Saura : obra gráfica : Serie Pintiquiniestras. Córdoba: Fundación Provincial de Arte Plásticas "Rafael Botí".

García Padrino, J. (2004). Formas y colores: la ilustración infantil en España. Cuenca: Servicio de Publicaciones de la Universidad de Castilla la Mancha.

Nöstlinger, C. (2010). El nuevo Pinocho: nueva versión de las aventuras de Pinocho de Carlo Collodi. Ilustrado por Antonio Saura. Meinier (Genève): Fundación Archives Antonio Saura; Barcelona: La Central; Madrid: Museo Nacional Centro de arte Reina Sofía.

Bonet, J.M; Maderuelo, J. (1997). Museo de Arte Abstracto Español. Fundación Juan March. Madrid: Arte y Ciencia. 